Article

\title{
Sustainability and Branding in Retail: A Model of Chain of Effects
}

\author{
Alfredo Flores-Hernández ${ }^{1}$, Ana Olavarría-Jaraba ${ }^{2, *}$, Guadalupe Valera-Blanes ${ }^{2}$ and \\ Rosario Vázquez-Carrasco ${ }^{2}$ \\ 1 Faculty of Business \& Economics, University of Lima, Lima 15023, Peru; Aflores@ulima.edu.pe \\ 2 Faculty of Business, University Pablo de Olavide, Ctra. de Utrera, km 1, 41013 Sevilla, Spain; \\ gvalbla@upo.es (G.V.-B.); rvazcar@upo.es (R.V.-C.) \\ * Correspondence: aolavarria@upo.es
}

Received: 1 July 2020; Accepted: 17 July 2020; Published: 19 July 2020

\begin{abstract}
The main objective of this study is to analyse the impact of sustainable practices on companies' corporate reputation and brand image in the retail sector as perceived by consumers. In addition, we evaluate how those practices affect consumers' perceived satisfaction levels and their predisposition to engage in positive Word of Mouth (WOM). For the purpose of this study, the context of an emerging economy, Peru, is taken as reference. To do this, we propose a structural equation model based on a representative sample of 403 consumers. The data analysis-using the PLS software package-confirms that corporate social responsibility (CSR) positively influences both corporate reputation and brand image. These two factors jointly have an impact on consumers' perceived satisfaction levels, which in turn help to explain the flow of positive WOM. This work is a pioneering study of the relationship between the aforementioned factors in the context of emerging economies. The final part of the article discusses the main theoretical implications and recommendations for business practice.
\end{abstract}

Keywords: retail; sustainability; CSR; reputation; brand image; WOM; emerging economy

This graphical abstract shows the proposed causal model as a chain of effects from the customers' perception of CSR to the perceived satisfaction and WOM in the retailing sector. This model aims to explain this phenomenon in the context of an emerging economy.

\section{Introduction}

Presently, society in general requires companies to follow sustainable and socially responsible business models [1]. Current consumption trends show an increasing interest in sustainable models [2-4], in products obtained from environmentally friendly production processes, in brands recognised for adopting fair practices in the management of their workers and in companies that support local communities or society in general. In short, in products and services offered by socially responsible companies that are committed to sustainability as a management reference $[1,5]$.

These business models are even more important in situations where companies face problems such as pressure from limitations in resources, fierce competition, diverse customer needs and the development of technology [5]. In the case of retail companies, trade dynamics are changing: the rapid expansion of ecommerce and online retailing [6] has encouraged omnichannel models and has forced many companies to consider logistical aspects (i.e., last mile logistics) in the value proposition. The latter have an impact not only on specific deliveries, but also on the $\mathrm{CO}_{2}$ footprint generated by each delivery [2]. Therefore, adopting best practices in terms of sustainability is a key factor to understand retailers' success $[7,8]$. 
In this sense, the work by Ruiz-Leal et al. [3] highlights the key role that the concept of sustainability is progressively acquiring in retail, regarded as an important source of competitive advantage. Based on an in-depth literature review, these authors identify different aspects of interest for academic research, notably: (i) the links between actions of sustainability and retailers' image; and (ii) how sustainability actions may influence brands. They also emphasise the relevance of international and cross-cultural analysis.

From a marketing viewpoint, understanding the extent to which sustainability principles can have an impact on reputation and/or brand image is essential to improve the company's commercial positioning. The literature review recognises the growing number of papers that analyse the phenomenon of sustainability and corporate social responsibility (CSR) in retailing. However, most of these works deal with the case of developed Western economies such as France [9] or Germany [10]. We found no evidence of similar studies in the context of emerging economies. However, analysing the role of sustainable retailing practices and their impact on corporate reputation and branding in emerging economies is relevant not only for research but also for practice. It seems increasingly important to conduct business in a sustainable manner.

The concept of sustainable development is not new and has matured over decades. In the 80s, the idea that economic growth was fundamental to development but closely linked to the specific local and historical sociocultural and institutional conditions of a country or community, and focused on the use of internal natural and human resources, was accepted. At that point, the idea that development needs to be sustainable was recognised, and the concept of sustainable development began to gain attention. Although there are several definitions of the concept of sustainable development, the most well-known is the one proposed by the Bruntland Commission Report in 1987, where sustainable development is defined as development that meets the needs of the current generation without compromising the ability of future generations to meet their own needs.

In terms of emerging economies, the challenge is how to reach economic growth following sustainable principles, as both poverty and inequality have been identified by the United Nations as the main obstacles for those economies to reach sustainable development goals. Therefore, the strategies based on sustainability and positively valued by customers may help to facilitate the economic growth of emerging economies, to reduce both absolute poverty and inequality and to guarantee the future of the next generations.

Therefore, after identifying these gaps in the literature, and having observed that they addressed a specific topic of this particular issue (i.e., the impact of sustainability practices on firm reputation and branding), this work aims to respond to the following research questions (RQs) in the context of emerging economies: Do the CSR activities perceived by customers impact on reputation and brand image? Does branding influence customers' perceived satisfaction and post-purchase behaviour?

These RQs result in four objectives: (i) to evaluate how sustainability principles (measured in CSR) have an impact on reputation and brand image; (ii) to assess how these factors affect consumers' perceived levels of satisfaction; (iii) to analyse the impact on consumers' predisposition to issue favourable opinions on products/brands (a key factor, given the great influence that opinions on social networks or search engines have on the choice of other consumers); and (iv) to deepen the analysis of consumption patterns in emerging economies.

To do this, the second section of this paper describes the theoretical background and hypotheses developed in this work. The third and fourth sections present the research methodology and results. Finally, we conclude with the main theoretical and practical implications of this study.

\section{Theoretical Background and Developed Hypotheses}

A key objective of any company is to establish and maintain firm and lasting relationships with its customers. Thus, relationship marketing aims to develop mutually satisfying long-term relationships with key stakeholders (consumers, employees and participants in the value chain) [11-16]. Despite the growing importance of stakeholders in business processes, companies have been changing not only 
the way in which they approach their objectives but also their own perception of who should be the beneficiaries of the created value [17]. In this context, the interest in sustainability as a reference management form is increasing [1]. Hart and Milstein [18] define sustainable value as "strategies and practices that contribute to a more sustainable world while simultaneously driving shareholder value". In other words, companies should continue to generate profit, but at the same time they are expected to increase their interest in the quality of their relationships with stakeholders and become more concerned with social and environmental issues [1,19-22]. In the same vein, different authors (i.e., [23,24]) consider that CSR has a positive effect on stakeholders (In this sense, the literature identifies three types of motives for companies to develop CSR activities [25]: (1) intrinsic: the company wishes to help and make a social contribution (altruistic vision); (2) extrinsic: the company expects to obtain financial or other benefits from its socially responsible behaviour; (3) addressing societal expectations and stakeholder pressure. Despite the existence of these different reasons, in practice, companies usually combine them and do not focus on just one of them.).

For this reason, CSR has been gaining importance among different interest groups [26], and especially among those consumers who have a greater motivation for consuming products from companies that are socially responsible/sustainable [27]. As a consequence, in recent years, there has been a growing interest in investigating the possible effect that CSR programmes have on consumer perceptions, behaviours and responses such as customer satisfaction. Most studies have found evidence of a significant influence of CSR practices [28-31]. This is due to the fact that consumers perceive stimuli and reward socially responsible companies through a series of pro-business behaviours (for example, through their purchases, loyalty or by defending the brand) [27].

From a theoretical point of view, Social Capital Theory and the Resource-Based View help to understand the possible impact of CSR on reputation, brand image and consumer responses. On the one hand, Social Capital Theory considers that social capital drives the pursuit of shared objectives. According to Putnam [32] and Kumar and Kumar [12], among others, social capital refers to connections among individuals, social networks and the norms or the reciprocity and trustworthiness that arise from them. As such, social capital reflects the extent to which the company's values meet society's standards and expectations $[33,34]$. Under this approach, CSR can be understood as a sign of transparency and benevolence, since it encourages cooperation and the exchange of information, which in turn promote relationships of trust between stakeholders. Thus, CSR can be considered as the forerunner of a solid long-term reputation [1,35-37] and brand image [38,39]. The latter constitutes a source of sustainable competitive advantage based on the differentiation from competitors.

On the other hand, the Resource-Based View (RBV) defends that the company is a heterogeneous set of resources and capacities whose sustained competitive advantage derives from its control over valuable, rare, difficult to imitate and non-substitutable resources and capacities [40,41]. Merely being in possession of these resources and capabilities, however, does not guarantee value creation or a competitive advantage: the latter depends on the company's ability to combine them [42]. Therefore, achieving competitive advantage involves formulating and implementing a strategy that exploits the company's unique characteristics [41]. In this sense, brand image and reputation play a key role: they represent intangible resources that can be unique and difficult to imitate, and therefore the source of a sustainable competitive advantage.

Different authors [43-45] highlight the increasing number of firms in retailing looking for ways to create strong emotional brand connections with consumers to achieve higher sales rates and more loyal customers. For this reason, the analysis of the impact of CSR activities on reputation, brand image and consumer responses is relevant in the retailing sector. Moreover, the role of brands as relationship builders between retailers and consumers is key [46], as in business-to-consumer (B2C) contexts some decisions are more emotional than rational [47].

We propose a model that establishes a chain of effects that starts from CSR activities and how they influence consumer satisfaction, both directly and indirectly, through reputation and brand image. 
In turn, consumer perceived satisfaction affects the recommendations consumers will make to other consumers (WOM). Figure 1 illustrates the reference causal model.

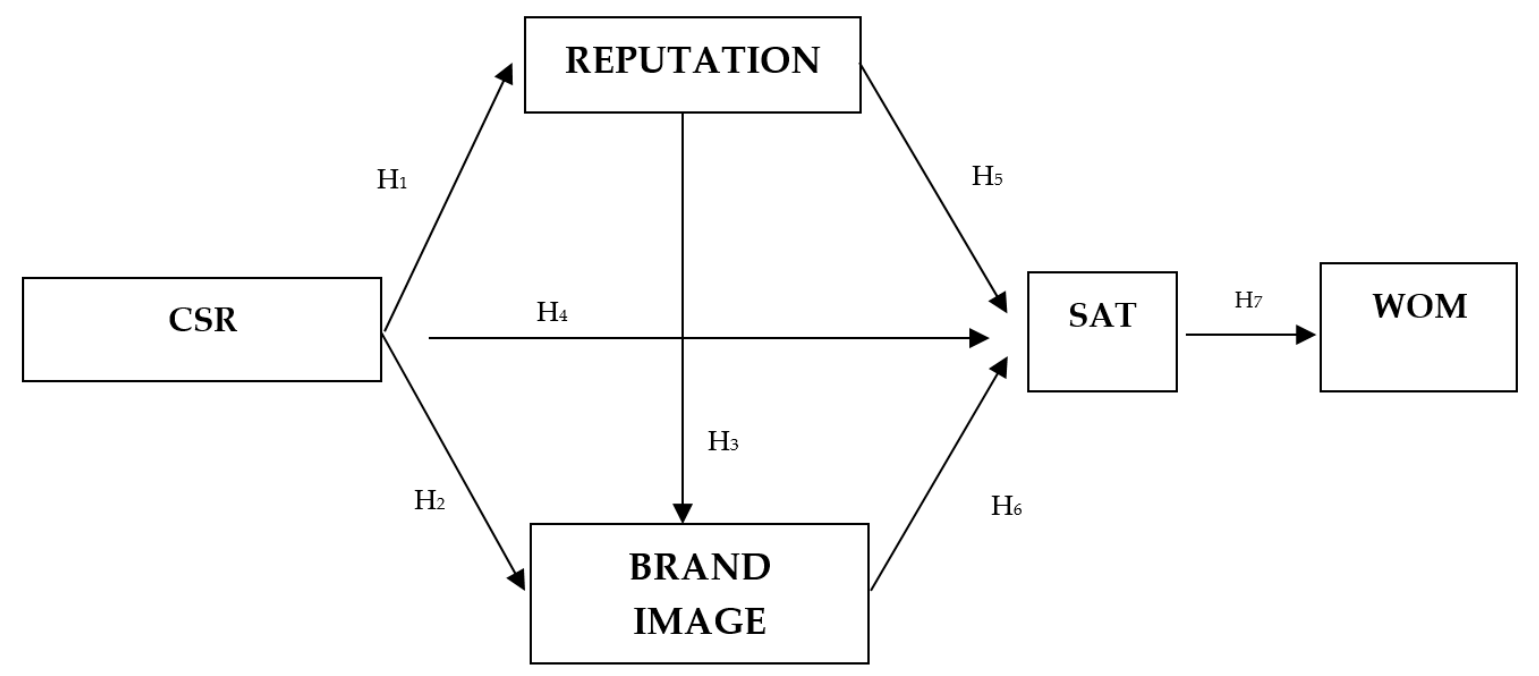

Figure 1. Reference Model.

\subsection{CSR, Brand Image and Reputation}

Both reputation and brand image are highly valuable intangible resources [48] that are positively influenced by CSR [1]. Reputation represents the perception of past acts and the projection of possible future acts representing the company's general attractiveness compared to its main rivals [49]. Reputation is primarily activated through the stakeholders' perceptions of the company [50]; it is dynamic in nature, since stakeholder perceptions can change, and the brand's reputation with them [51]. In this sense, many CSR activities are perceived by stakeholders as evidence of the company's predisposition towards sustainability, thereby generating positive feelings and attitudes towards the company [52]. For this reason, companies use CSR as a strategic tool to respond to stakeholder expectations and to build and preserve their reputation [29].

Brand image refers to the utility or added value that the brand brings to the product [53]. Armstrong et al. [11] suggest that brand image reflects what the consumer has stored of the brand in his memory - that is, basically, what comes to a consumer's mind when placed in front of the brand. Therefore, brand image contributes to determining present and future positioning [52]. Brands based on emotional values are more durable in nature and less likely to be worn down by competing actions [54]. Therefore, CSR actions can contribute to a brand image's emotional component [55]. There is a broad consensus that CSR positively influences customers' brand perceptions [38,56,57]. Authors such as Holt et al. [58] and Kim and Li [38] believe that social responsibility acts as an enhancer of global brand evaluations. Therefore, perceptions about the company's CSR add value to the brand's image [59].

We thus understand that previous studies indicate that CSR positively influences both reputation [60,61] and brand image [59,62,63]. However, in the context of emerging economies, there is only a small and very recent body of literature suggesting these ideas $[20,57,64-66]$. Therefore, we put forward the following hypotheses:

Hypothesis 1. CSR positively influences corporate reputation.

Hypothesis 2. CSR positively influences brand image.

On the other hand, corporate reputation is strongly linked to brand image [67]. CSR's share-based reputation is an intangible resource that is difficult to imitate, since it contributes to creating a relationship of trust between companies and their stakeholders $[37,68]$. In the case of consumers, 
reputation can influence their behaviour [35,69-73]. More specifically, reputation can lead to a positive attitude towards the company and its success [74], but also translate into a more favourable attitude and a higher level of consumer loyalty towards the company's products [1]. This greater predisposition towards a company's products can be explained by the added value that the brand brings to the product, that is, the brand image perceived by consumers. Therefore, a strong reputation based on positive perceptions of CSR activities influences the brand image [48,52], since many consumers value CSR-based reputation as a key factor in their positive perception of a given brand $[52,64,67,75]$. Having all of this in mind, we propose our third hypothesis:

Hypothesis 3. Reputation positively influences brand image.

\subsection{CSR and Satisfaction}

Satisfaction can be defined as the degree to which previous expectations are met or exceeded with the acquisition of a good or service, constituting a positive emotional state based on all the aspects derived from its analysis [76].

Consumer decisions are affected by various factors, such as value for money, climate change or financial differences in developed countries resulting from economic crises [59]. Thus, consumers' needs go beyond the benefits they can obtain from the product itself. Price and quality are no longer the main source of competitive advantage to stimulate consumer responses to the company, but rather aspects such as the company's ethics and social practices [77].

Various studies have shown that consumers prefer socially responsible companies [78]. In particular, the study conducted by Becker-Olsen et al. [79] found that over $80 \%$ of respondents believed that companies should engage in social initiatives and that $52 \%$ of respondents would boycott companies that did not carry out CSR initiatives if there were other alternatives available on the market.

Previous work has shown a positive influence of CSR on customer satisfaction [80]. Once again, there is only a small and very recent body of literature regarding the analysis of the case of emerging economies [81,82], which reinforces the newness of our proposal. Based on the above, we propose the following hypothesis:

Hypothesis 4. CSR positively influences consumer perceived satisfaction.

On the other hand, people's attitudes and behaviours can be indirectly affected by the fit between the company and its CSR activities. In this sense, according to De Jong and Van der Meer [25], aspects such as sincerity and credibility are relevant. Furthermore, CSR programmes have a significant influence on how a consumer perceives both products and companies [83].

We can infer that satisfaction does not come from the product or service itself, but rather it is derived from consumers' perceptions of the products or services. In this respect, satisfaction can be defined as the difference between the consumers' perceptions of the product and their prior expectations [84]. Both reputation and brand image can play a key role in this regard. Brand image and reputation can enhance consumers' perceptions of product use and determine the degree to which a brand meets their demands and expectations [85,86]. Thus, consumers may feel esteem or disdain towards a company based not only on their direct experiences of the company, but also on reputation-related information [87] and on brand associations present in consumers' memories [88]. Purchase decisions respond to an evaluation of the attributes, a favourable brand image and a favourable brand attitude; a positive image generates positive consumer perceptions that will in turn contribute to consumer satisfaction [55]. Recent literature highlights that brand image has a significant impact on perceptions of value and satisfaction [89]. These arguments allow us to establish the following block of hypotheses:

Hypothesis 5. Corporate reputation positively influences consumer perceived satisfaction. 
Hypothesis 6. Brand image positively influences consumer perceived satisfaction.

\subsection{Satisfaction and WOM}

One result sought by marketing managers is that consumers are willing to spread positive opinions in their social environment [90]. Word of Mouth is defined as the communication established between two people in which the recipient understands that the information provided about a service, product or brand is not commercial [91]. WOM is a form of communication established between consumers and is based on personal experiences and evaluations regarding a company or a product [92]. Therefore, it is logical to believe that for a consumer to recommend a product or a company, he or she must have had prior positive experiences and evaluations, that is, he or she must be satisfied. In this sense, the literature has closely linked satisfaction with various consumer positive behavioural intentions, such as positive WOM interactions [93]. The above allows us to establish our last hypothesis:

Hypothesis 7. Consumer perceived satisfaction positively influences WOM.

\section{Methodology}

To test our hypotheses, we conducted a study in the Peruvian food and beverages retail sector. Underlying our analysis of habitual consumption patterns is the fact that food and beverage products-together with textile, health and transport-are considered frequent consumption products in the Peruvian shopping basket [94]. Our study population comprised consumers over 18 years old in Lima's metropolitan area. The metropolitan area of the capital of Peru is home to over $30 \%$ of the country's population, representing all age groups, training and income levels-and the area is considered the economic and demographic engine of the country. Table 1, below, shows the technical data for our study.

Peru remains a stable economy in Latin America (LATAM) with a regionally high growth rate, around $4 \%$. According to a study by Atradius [95], a trade credit insurer, Peru is considered one of the most promising emerging economies in the world, with notable growth prospects in 2019 for its primary industry sector. It should also be noticed that Peru has signed trade agreements with the US, the European Union (EU), China, Mercosur and Australia.

We used a face-to-face questionnaire. The data collection took place over a three-month period during scheduled times (morning, afternoon and evening), seven days a week. Interceptions occurred near the supermarkets, convenience stores and mall entrances and exits to reduce sampling bias and to obtain a mix of respondents, as suggested by Kok and Fon [96]. Interception is a popular method in marketing research [97] and has been used in similar studies [98,99]. The method is appropriate for our analysis because it enables interviewers to screen potential respondents for their eligibility and to seek clarification if needed [98].

Table 1. Technical data of the fieldwork.

\begin{tabular}{cc}
\hline Universe & $\begin{array}{c}\text { Consumers of Food and Beverage Products, over 18 Years of Age, from the } \\
\text { Metropolitan Lima Area (Peru) }\end{array}$ \\
\hline Sample size & 403 \\
\hline Geographical scope & National. Peru \\
\hline Sampling method & Random quota \\
\hline Fieldwork & October-December, 2018 \\
\hline Sampling error & $4.9 \%(\mathrm{p}=\mathrm{q}=0.5 ; \mathrm{z}=1.96 ; 95 \%)$ \\
\hline Analysis of information & PLS Software (SmartPLS 3.2.7) \\
\hline
\end{tabular}


The questionnaire used was adapted from previously validated and contrasted scales to measure each of the constructs (see Appendix A). Interviewees had to think of F\&B brands they associated with CRS practices-in order to avoid potential misunderstandings, some examples of good practices were provided. All the constructs included in this study can be considered as design constructs or artefacts; that is to say, human-made instruments theoretically justified and typically created by managers and staff in companies [100]. Since such artefacts are shaped from a series of elementary parts or components, which are combined to form a new entity, Henseler [100] suggests modelling them as composites. As we aimed to estimate a model of composites, a structural equation modelling technique was employed to analyse the proposed model, using partial least squares (PLS) (SmartPLS v. 3.2.7) [101,102].

\section{Results}

Given that our study has a confirmatory purpose, we begin the analysis of the estimated model by providing the goodness of fit value (0.655), which is higher than the reference value of 0.4 proposed by Tenenhaus et al. [103]. Therefore, the model presents a good quality of fit. With the objective of evaluating the quality of the data, we carried out an individual reliability analysis of each item relative to its construct. All resulting values exceed the threshold of 0.707 required by Carmines and Zeller [104]. The same was found when assessing the reliability of the variables using Cronbach's alpha and composite reliability. Appendix A shows that all constructs are reliable, as they exceed the reference value of 0.8 for each index [105]. The convergent validity was assessed using the average variance extracted (AVE), which, according to Fornell and Larcker [106], must exceed 0.5. As such, over 50\% of the variance of the construct was found to be due to the recommended indicators. Appendix A shows that the reference value was exceeded in all cases. Finally, the existence of discriminant validity was validated applying the comparison of the square root of AVE against correlations (see Table 2).

Table 2. Discriminant.

\begin{tabular}{cccccc}
\hline & Brand Image & CSR & Reputation & Satisfaction & WOM \\
\hline Brand image & $\mathbf{0 . 8 0 3}$ & & & & \\
\hline CSR & 0.578 & $\mathbf{0 . 8 7 5}$ & & & \\
\hline Reputation & 0.798 & 0.563 & $\mathbf{0 . 8 4 7}$ & & \\
\hline Satisfaction & 0.603 & 0.569 & 0.570 & $\mathbf{0 . 9 3 1}$ & \\
\hline WOM & 0.508 & 0.512 & 0.479 & 0.723 & $\mathbf{0 . 9 4}$ \\
\hline
\end{tabular}

The numbers in bold along the diagonal axis are the square roots of the average variance extracted (AVE) for the variables; the rest of the numbers represent construct correlations. All correlations are significant at $<0.01$ [81].

Regarding the structural model, a bootstrap analysis was performed to assess the statistical significance of the loadings and the path coefficients. We created 5000 subsamples, employing t-Student distribution with 4999 degrees of freedom $(\mathrm{N}-1$, where $\mathrm{N}=$ number of subsamples), obtaining the values $\mathrm{t}_{(0.05 ; 4999)}=1.64 ; \mathrm{t}_{(0.01 ; 4999)}=2.32$; and $\mathrm{t}_{(0.001 ; 4999)}=3.09$. From these values, we determined the acceptance or rejection of our hypotheses (see Table 3, below). Concerning the explained variance of the endogenous variables $\left(R^{2}\right)$, the model shows adequate predictive power, since all of the endogenous constructs achieved an explained variance greater than 0.1 , the reference value established by Falk and Miller [107].

The data shown in Table 3 highlight that, as predicted, all the links between constructs are significant. As such, all the hypotheses can be confirmed, and the first step of the chain of effects model we propose has been proved to occur, starting from CSR. Thus, by accepting $\mathrm{H}_{1}, \mathrm{H}_{2}$ and $\mathrm{H}_{4}$, we confirm that CSR has a direct and significant link to reputation, brand image and perceived satisfaction. Reputation positively influences brand image $\left(\mathrm{H}_{3}\right)$. Moreover, we also find that both reputation and brand image directly influence satisfaction (confirming $\mathrm{H}_{5}$ and $\mathrm{H}_{6}$ ). Finally, our chain of effects model shows a direct and positive link between perceived satisfaction and WOM $\left(\mathrm{H}_{7}\right)$. 
Table 3. Structural model results.

\begin{tabular}{cccc}
\hline Hypothesis & B & $t$-Value & $\mathbf{R}^{\mathbf{2}}$ \\
\hline $\mathrm{H}_{1}: \mathrm{CSR}->\mathrm{REP}$ & $0.153^{* *}$ & 3.048 & 0.652 \\
\hline $\mathrm{H}_{2}: \mathrm{CSR}->\mathrm{B}$ IMAG & $0.578^{* * *}$ & 15.986 & \\
\hline $\mathrm{H}_{3}: \mathrm{REP}->\mathrm{B}$ IMAG & $0.709^{* * *}$ & 16.054 & 0.334 \\
\hline $\mathrm{H}_{4}: \mathrm{CSR}->\mathrm{SAT}$ & $0.307^{* * *}$ & 4.909 & 0.445 \\
\hline $\mathrm{H}_{5}: \mathrm{REP}->\mathrm{SAT}$ & $0.159^{*}$ & 1.948 & \\
\hline $\mathrm{H}_{6}: \mathrm{B} \mathrm{IMAG}->\mathrm{SAT}$ & $0.298^{* * *}$ & 4.663 & \\
\hline $\mathrm{H}_{7}: \mathrm{SAT}->$ WOM & $0.723^{* * *}$ & 27.301 & 0.522 \\
\hline
\end{tabular}

*** When the $t$ value obtained by the Bootstrap technique overcomes the $\mathrm{T}$ Student value $\mathrm{t}_{(0.001,4999)}=3.09$, the hypothesis is accepted with $99.9 \%$ significance; ${ }^{* *}$ When the $t$ value obtained by the Bootstrap technique overcomes the T Student value $t_{(0.01,4999)}=2.32$, the hypothesis is accepted at $99 \%$ significance; ${ }^{*}$ When the $t$ value obtained by the Bootstrap technique overcomes the T Student value $t_{(0.05,4999)}=1.64$, the hypothesis is accepted at $95 \%$ significance.

\section{Discussion and Conclusions}

Sustainability is playing an increasingly important role in commercial management [1,5]. In fact, a greater number of companies are incorporating sustainability principles in their values and policies, and the retail sector is no exception [2,3]. Consumption patterns are changing at a dizzying rate, and companies must adapt to them. As such, the present study examines the impact of retail companies' sustainability actions-measured based on the CSR concept—on consumer satisfaction levels and their predisposition to generate positive WOM through a chain of effects that considers corporate reputation and brand image as transmitters of such CSR actions. In this sense, our research is compatible with the proposal of Ruiz-Leal et al. [3], who draw attention to the growing importance of promoting sustainable practices in retail, while calling for a greater number of empirical studies on the potential links between sustainability actions and retailers' image/brands.

Previous studies have signalled the existence of positive relationships between CSR and reputation $[1,60,64]$ and also between CSR and brand image [38,55-58]. Nevertheless, there is a big gap in research, as these basic models need to be expanded to cover post-purchase behaviours of a non-transactional type (i.e., WOM). Furthermore, none of them had so far studied the case of an emerging economy. Taking into account the fact that economic growth is not always achieved following the rules of sustainability and that the resulting production and consumption patterns can generate negative externalities such as income inequalities, pollution and depletion of natural resources, analysing the case of emerging economies is of great interest. In particular, it is important to know in what way consumers in emerging economies, in their dual role as consumers and citizens, perceive and value companies' sustainable efforts. Our results are very encouraging, as they show that, in line with the general body of literature, consumers in these economies have a positive attitude towards the CSR actions implemented by retailing companies.

Specifically, the results of our study support those of previous works $[1,38,55,57]$ that recognise the existence of a positive link between CSR and reputation and perceived brand image. In addition, we identified a positive chain of effects that confirms a positive link between CSR and consumers' perceived level of satisfaction [78,79], also in the context of emerging economies [81,82]. This idea is relevant because, until now, there was only scarce evidence in this regard in the case of emerging economies, characterised by lower income levels and less awareness of the concept of sustainability. However, our data reveals that sensitivity to sustainability exists on a global scale: appropriate actions have an impact on the market's perception of the brands and products that assume these sustainable principles, and the latter reinforce the products' intrinsic characteristics. Therefore, regardless of the motives that drive companies towards practices compatible with sustainability and 
social responsibility—whether intrinsic or extrinsic motives, stakeholder pressure or a combination of both [25] - their importance is clear across widely diverse contexts: geographic, cultural, sectorial.

It seems clear that generating a positive link with products will facilitate customer loyalty. This idea becomes crucial in the retail sector, since in many cases we observe that this sector deals with products that are everyday consumer products (food and beverages, in our study). Since brands are recognised as building relationships between retailers and customers $[43,46]$ through the creation of emotional bonds [44,46], our analysis becomes quite relevant. If firms develop CSR practices and are able to communicate them to customers, a positive market attitude in terms of reputation, brand image and perceived satisfaction may create adequate patterns of consumption, sharing the co-responsibility for a sustainable development.

As our results show, we can be optimistic, as there is a path to achieve sustainable growth in emerging economies. In this sense, from a practical point of view, we must recommend the adoption of sustainable manufacturing practices, compatible with the principles of economic, social and environmental sustainability, but also sustainable distribution and communication practices. Retailing companies must be aware of their carbon footprint, regardless of whether they use physical points of sale or online order delivery (e.g., the last mile). Furthermore, we strongly recommend complementing these actions with a proper communication strategy, through web pages, social networks, advertising and applying adapted product labelling - all of this for purposes of commercial positioning and differentiation from competitors. This way, companies will be able to build relevant competitive advantages. Nevertheless, as the Social Capital Theory [12,32,34] points out, these actions must respond to real criteria and never to one-off and opportunistic stimuli. Otherwise, companies run the risk of being penalised by the market. Sustainability must be integrated into the core of the company's activity, in its DNA.

Our results also show that higher levels of consumer satisfaction drive their predisposition towards positive WOM. This idea is present in general marketing literature $[90,108]$. However, it had not been analysed until now regarding CSR actions, and our research can be considered as pioneer. Thus, from a practical point of view, we must recommend ensuring that the product meets the standards anticipated by consumers, that their expectations are met and that the product or service conforms to the company's sustainability standards. Misleading advertising, as highlighted in the previous paragraph, is never a good idea. Furthermore, companies can reinforce the effect of satisfaction using other types of actions that encourage customers to express favourable opinions. Promoting raffles, giving loyalty points and establishing different levels of relationship with the company are useful tools to spur consumers, assuming that they will respond positively as long as they are satisfied with the product/service. These initiatives will be all the more important the greater the effect of social networks or search engines on the information search process. In addition, the devastating effect of a negative WOM must be taken into account.

Therefore, both from a theoretical and a practical viewpoint, we advocate building a solid corporate reputation based on CSR. This will be possible when sustainability becomes a reference in any company's management, generally, and in retail companies in particular. The brand image will become an intangible asset of great value, that will reinforce the consumers' decision process and their level of satisfaction regarding the product or service purchased. If companies are capable of generating this virtuous cycle, they can expect positive, non-transactional behaviours of great value, such as WOM. Moreover, from a theoretical point of view, it will reinforce both the reputation and brand image, as well as the company's future positioning.

Despite the theoretical and practical relevance of this research, we must recognise some limitations. Results were based on surveys, not actual behavioural data. We used a number of procedural strategies to address potential bias and to ensure data validity [109]: ensuring participant anonymity; clarifying that there were no right or wrong answers; using previously validated scales; and developing a pre-test to avoid possible ambiguities in the scales' wording. In addition, the data are limited to one specific country. However, given that the few studies on the subject to date work with samples from developed 
economies, rooting our research in the analysis of an emerging economy can only enhance the relevance of our study and its contribution to the literature. From our perspective, it would be interesting to complete the study with other non-transactional behaviours, such as the willingness of consumers to co-create, as additional outcomes to our chain of positive effects. Finally, replicating the study in other emerging countries would be of great interest to improve our knowledge about different consumer reaction patterns before CSR actions are developed in companies and, in this way, reinforce the role of CSR in business activity generally and commercial activity in particular.

Author Contributions: Conceptualization: A.F.-H., A.O.-J. and G.V.-B.; methodology, software and data analysis: R.V.-C. and A.F.-H.; writing: A.F.-H., A.O.-J., G.V.-B. and R.V.-C. All authors have read and agreed to the published version of the manuscript.

Funding: This research received no external funding

Conflicts of Interest: The authors declare no conflicts of interest.

\section{Appendix A}

Table A1. Measurement Scales (Sources) (Alpha C., FC., AVE)/Mean/Standard Deviation.

\begin{tabular}{|c|c|c|}
\hline CONSTRUCT/ITEMS & Mean & St Dev \\
\hline \multicolumn{3}{|l|}{ 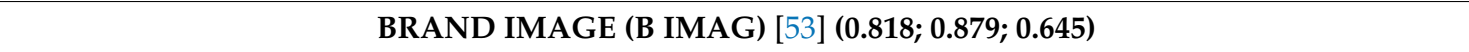 } \\
\hline B1. The [brand] logo is easily recognised. & 6.635 & 3.500 \\
\hline B2. My social environment is aware of the values conveyed by [brand]. & 5.087 & 1.407 \\
\hline B3. I think [brand] stands out among its competitors. & 6.092 & 1.061 \\
\hline B4. I think [brand] is easily remembered by consumers. & 6.427 & 0.959 \\
\hline B5. Society can rely on [brand]. & 5.481 & 1.345 \\
\hline \multicolumn{3}{|l|}{ CORPORATE SOCIAL RESPONSIBILITY (CSR) [53] (0.898; 0.929; 0.766) } \\
\hline CSR1. I consider [brand] to be socially responsible. & 4.868 & 1.398 \\
\hline CSR2. [Brand] is committed to promoting well-being in society. & 4.789 & 1.462 \\
\hline CSR3. [Brand] is environmentally friendly. & 4.697 & 1.513 \\
\hline CSR4. The human resources management of [brand] goes beyond legal requirements. & 4.530 & 1.416 \\
\hline \multicolumn{3}{|l|}{ REPUTATION (REP) [59] (0.900; 0.926; 0.717) } \\
\hline R1. I think [brand] has a good reputation. & 5.608 & 1.351 \\
\hline R2. I think [brand] is well known. & 6.467 & 0.997 \\
\hline R3. I think [brand] is admired. & 5.583 & 1.280 \\
\hline R4. I think [brand] is prestigious. & 5.811 & 1.248 \\
\hline R5. Overall, I think [brand] has a good reputation. & 5.759 & 1.260 \\
\hline \multicolumn{3}{|l|}{ SATISFACTION (SAT) [84] $(0.949 ; 0.963 ; 0.867)$} \\
\hline S1. My relationship with [brand] has been positive. & 4.772 & 1.596 \\
\hline $\begin{array}{l}\text { S2. Compared to what my ideal relationship would be, I am very satisfied with my } \\
\text { relationship with [brand]. }\end{array}$ & 4.752 & 1.535 \\
\hline S3. Overall, I am very satisfied with [brand]. & 5.005 & 1.449 \\
\hline S4. I am very satisfied with [brand], as it has fulfilled my expectations. & 4.968 & 1.488 \\
\hline \multicolumn{3}{|l|}{ WORD OF MOUTH (WOM) [90] (0.869; 0.938; 0.883) } \\
\hline WOM1. I like to share my experiences as a [brand] customer with others. & 4.417 & 1.701 \\
\hline WOM2. I'll recommend [brand] to friends and family. & 4.643 & 1.663 \\
\hline WOM3. I always give my honest opinion about [brand] services. & 5.821 & 1.339 \\
\hline
\end{tabular}




\section{References}

1. López-Pérez, M.E.; Melero-Polo, I.; Vázquez-Carrasco, R.; Cambra-Fierro, J.J. Sustainability and Business Outcomes in the Context of SMEs: Comparing Family Firms vs. Non-Family Firms. Sustainability 2018, 10, 4080. [CrossRef]

2. Olsson, J.; Hellström, D.; Palsson, H. Framework of Last Mile Logistics Research: A Systematic Review of the Literature. Sustainability 2019, 11, 7131. [CrossRef]

3. Ruiz-Real, J.L.; Uribe-Toril, J.; Gázquez-Abad, J.C.; Valenciano, J.D.P. Sustainability and Retail: Analysis of Global Research. Sustainability 2019, 11, 14. [CrossRef]

4. Kumar, B.; Manrai, A.K.; Manrai, L.A. Purchasing behaviour for environmentally sustainable products: A conceptual framework and empirical study. J. Retail. Consum. Serv. 2017, 34, 1-9. [CrossRef]

5. Zhang, N.; Mei, L. Sustainable Development in the Service Industry: Managerial Learning and Management Improvement of Chinese Retailers. Sustainability 2020, 12, 1430. [CrossRef]

6. Rao, F. Resilient Forms of Shopping Centers Amid the Rise of Online Retailing: Towards the Urban Experience. Sustainability 2019, 11, 3999. [CrossRef]

7. Claro, D.P.; Silvio Abrahao, L.N.; de Priscila Borin, O.C. Sustainability drivers in food retail. J. Ret. Cons. Serv. 2013, 20, 365-371. [CrossRef]

8. Meise, J.N.; Rudolph, T.; Kenning, P.; Phillips, D.M. Feed them facts: Value perceptions and consumer use of sustainability-related product information. J. Retail. Consum. Serv. 2014, 21, 510-519. [CrossRef]

9. Kessous, A.; Boncori, A.-L.; Paché, G. Are consumers sensitive to large retailers' sustainable practices? A semiotic analysis in the French context. J. Retail. Consum. Serv. 2016, 32, 117-130. [CrossRef]

10. Moser, A.K. Consumers' purchasing decisions regarding environmentally friendly products: An empirical analysis of German consumers. J. Retail. Consum. Serv. 2016, 31, 389-397. [CrossRef]

11. Armstrong, G.; Kotler, P.; Harker, M.; Brennan, R. Marketing: An Introduction; Prentice Hall: Upper Saddle River, NJ, USA, 2009.

12. Kumar, J.; Kumar, V. Drivers of brand community engagement. J. Retail. Consum. Serv. 2020, 54, 101949. [CrossRef]

13. Garriga, E.; Mele, D. Corporate Social Responsibility Theories: Mapping the Territory. J. Bus. Ethics 2004, 53, 51-71. [CrossRef]

14. Arslanagic-Kalajdzic, M.; Kadic-Maglajlic, S.; Miocevic, D. The power of emotional value: Moderating customer orientation effect in professional business services relationships. Ind. Mark. Manag. 2020, 88, 12-21. [CrossRef]

15. Alvarez-Milan, A.; Felix, R.; Rauschnabel, P.A.; Hinsch, C. Strategic customer engagement marketing: A decision making framework. J. Bus. Res. 2018, 92, 61-70. [CrossRef]

16. Gupta, S.; Foroudi, P.; Yen, D. Investigating relationship types for creating brand value for resellers. Ind. Mark. Manag. 2018, 72, 37-47. [CrossRef]

17. Cardoni, A.; Kiseleva, E.; Taticchi, P. In Search of Sustainable Value: A Structured Literature Review. Sustainability 2020, 12, 615. [CrossRef]

18. Hart, S.L.; Milstein, M.B. Creating sustainable value. Acad. Manag. Perspect. 2003, 17, 56-67. [CrossRef]

19. Cuervo-Cazurra, A. The Evolution of Business Groups' Corporate Social Responsibility. J. Bus. Ethics 2019, 153, 997-1016. [CrossRef]

20. Shirodkar, V.; Beddewela, E.; Richter, U.H. Firm-Level Determinants of Political CSR in Emerging Economies: Evidence from India. J. Bus. Ethics 2019, 148, 673-688. [CrossRef]

21. Castro, G.M.-D.; Amores-Salvadó, J.; Navas-López, J.E. Environmental Management Systems and Firm Performance: Improving Firm Environmental Policy through Stakeholder Engagement. Corp. Soc. Responsib. Environ. Manag. 2016, 23, 243-256. [CrossRef]

22. Russo, A.; Perrini, F. Investigating Stakeholder Theory and Social Capital: CSR in Large Firms and SMEs. J. Bus. Ethics 2010, 91, 207-221. [CrossRef]

23. Saridakis, C.; Angelidou, S.; Woodside, A.G. What type of CSR engagement suits my firm best? Evidence from an abductively-derived typology. J. Bus. Res. 2020, 108, 174-187. [CrossRef]

24. Turker, D. Measuring Corporate Social Responsibility: A Scale Development Study. J. Bus. Ethics 2009, 85, 411-427. [CrossRef] 
25. De Jong, M.D.T.; Van Der Meer, M. How Does It Fit? Exploring the Congruence Between Organizations and Their Corporate Social Responsibility (CSR) Activities. J. Bus. Ethics 2017, 143, 71-83. [CrossRef]

26. Kiessling, T.; Isaksson, L.; Yasar, B. Market Orientation and CSR: Performance Implications. J. Bus. Ethics 2016, 137, 269-284. [CrossRef]

27. Baskentli, S.; Sen, S.; Du, S.; Bhattacharya, C. Consumer reactions to corporate social responsibility: The role of CSR domains. J. Bus. Res. 2019, 95, 502-513. [CrossRef]

28. Dang, V.T.; Nguyen, N.; Pervan, S. Retailer corporate social responsibility and consumer citizenship behavior: The mediating roles of perceived consumer effectiveness and consumer trust. J. Retail. Consum. Serv. 2020, 55, 102082. [CrossRef]

29. Arikan, E.; Kantur, D.; Maden, C.; Telci, E.E.; Arıkan, E. Investigating the mediating role of corporate reputation on the relationship between corporate social responsibility and multiple stakeholder outcomes. Qual. Quant. 2016, 50, 129-149. [CrossRef]

30. Zasuwa, G. Do the ends justify the means? How altruistic values moderate consumer responses to corporate social initiatives. J. Bus. Res. 2016, 69, 3714-3719. [CrossRef]

31. Smith, C. Corporate social responsibility: Whether or how? Calif. Manag. Rev. 2003, 45, 52-76. [CrossRef]

32. Putnam, R.D. Bowling Alone; Simon and Schuster: New York, NY, USA, 2000.

33. Cesar, S.; Jhony, O. Corporate Social Responsibility supports the construction of a strong social capital in the mining context: Evidence from Peru. J. Cl. Prod. 2020, 267-275. [CrossRef]

34. Sen, S.; Cowley, J. The Relevance of Stakeholder Theory and Social Capital Theory in the Context of CSR in SMEs: An Australian Perspective. J. Bus. Ethics 2013, 118, 413-427. [CrossRef]

35. Lin, H.; Zeng, S.; Wang, L.; Zou, H.; Ma, H. How Does Environmental Irresponsibility Impair Corporate Reputation? A Multi-Method Investigation. Corp. Soc. Responsib. Environ. Manag. 2016, 23, 413-423. [CrossRef]

36. Orlitzky, M.; Siegel, D.S.; Waldman, D.A. Strategic Corporate Social Responsibility and Environmental Sustainability. Bus. Soc. 2011, 50, 6-27. [CrossRef]

37. Stanaland, A.J.S.; Lwin, M.O.; Murphy, P.E. Consumer Perceptions of the Antecedents and Consequences of Corporate Social Responsibility. J. Bus. Ethics 2011, 102, 47-55. [CrossRef]

38. Kim, S.; Lee, H. The Effect of CSR Fit and CSR Authenticity on the Brand Attitude. Sustainability 2020, 12, 275. [CrossRef]

39. Hsu, K.-T. The Advertising Effects of Corporate Social Responsibility on Corporate Reputation and Brand Equity: Evidence from the Life Insurance Industry in Taiwan. J. Bus. Ethics 2012, 109, 189-201. [CrossRef]

40. Gupta, A.K.; Gupta, N. Effect of corporate environmental sustainability on dimensions of firm performance-Towards sustainable development: Evidence from India. J. Clean. Prod. 2020, 253, 119948. [CrossRef]

41. Grant, R.M. The Resource-Based Theory of Competitive Advantage: Implications for Strategy Formulation. Calif. Manag. Rev. 1991, 33, 114-135. [CrossRef]

42. Martelo, S.; Barroso-Castro, C.; Cepeda, G.; Martelo-Landroguez, S. The use of organizational capabilities to increase customer value. J. Bus. Res. 2013, 66, 2042-2050. [CrossRef]

43. Iyer, P.; Davari, A.; Srivastava, S.; Paswan, A.K. Market orientation, brand management processes and brand performance. J. Prod. Brand Manag. 2020. [CrossRef]

44. Veloutsou, C.; Guzmán, F. The evolution of brand management thinking over the last 25 years as recorded in the Journal of Product and Brand Management. J. Prod. Brand Manag. 2017, 26, 2-12. [CrossRef]

45. Malär, L.; Krohmer, H.; Hoyer, W.D.; Nyffenegger, B. Emotional Brand Attachment and Brand Personality: The Relative Importance of the Actual and the Ideal Self. J. Mark. 2011, 75, 35-52. [CrossRef]

46. Fetscherin, M.; Guzmán, F.; Veloutsou, C.; Cayolla, R.R. Latest research on brand relationships: Introduction to the special issue. J. Prod. Brand Manag. 2019, 28, 133-139. [CrossRef]

47. Schau, H.J.; Muñiz, A.M.; Arnould, E.J. How Brand Community Practices Create Value. J. Mark. 2009, 73, 30-51. [CrossRef]

48. Cowan, K.; Guzmán, F. How CSR reputation, sustainability signals, and country-of-origin sustainability reputation contribute to corporate brand performance: An exploratory study. J. Bus. Res. 2020. [CrossRef]

49. Fombrun, C. Reputation. In Realizing Value from the Corporate Image; Harvard Business School Press: Boston, MA, USA, 1996. 
50. Helm, S. The Role of Corporate Reputation in Determining Investor Satisfaction and Loyalty. Corp. Reput. Rev. 2007, 10, 22-37. [CrossRef]

51. Mehtap, O.; Kokalan, O. The relationship between corporate reputation and organizational citizenship behavior: A comparative study on TV companies and banks. Qual. Quant. 2012, 47, 3609-3619. [CrossRef]

52. Torres, A.; Bijmolt, T.H.; Tribo, J.A.; Verhoef, P. Generating global brand equity through corporate social responsibility to key stakeholders. Int. J. Res. Mark. 2012, 29, 13-24. [CrossRef]

53. Hur, W.-M.; Kim, H.; Woo, J. How CSR Leads to Corporate Brand Equity: Mediating Mechanisms of Corporate Brand Credibility and Reputation. J. Bus. Ethics 2014, 125, 75-86. [CrossRef]

54. Lynch, J.; De Chernatony, L. The power of emotion: Brand communication in business-to-business markets. J. Brand Manag. 2004, 11, 403-419. [CrossRef]

55. Ramesh, K.; Saha, R.; Goswami, S.; Dahiya, R. Consumer's response to CSR activities: Mediating role of brand image and brand attitude. Corp. Soc. Responsib. Environ. Manag. 2019, 26, 377-387. [CrossRef]

56. Rust, R.; Zeithaml, V.; Lemmon, K. Driving Customer Equity; The Free Press: New York, NY, USA, 2000.

57. Li, J.; Zhang, F.; Sun, S. Building Consumer-Oriented CSR Differentiation Strategy. Sustainability 2019, 11, 664. [CrossRef]

58. Holt, D.B.; Quelch, J.A.; Taylor, E.L. How global brands compete. Harv. Bus. Rev. 2004, 82, 68-75.

59. Martínez, P.; Pérez, A.; Del Bosque, I.R. CSR influence on hotel brand image and loyalty. Academia Revista Latinoamericana de Administración 2014, 27, 267-283. [CrossRef]

60. Melo, T.; Garrido-Morgado, A. Corporate Reputation: A Combination of Social Responsibility and Industry. Corp. Soc. Responsib. Environ. Manag. 2012, 19, 11-31. [CrossRef]

61. Brammer, S.; Pavelin, S. Corporate Reputation and Social Performance: The Importance of Fit. J. Manag. Stud. 2006, 43, 435-455. [CrossRef]

62. Lauritsen, B.D.; Perks, K.J. The influence of interactive, non-interactive, implicit and explicit CSR communication on young adults' perception of UK supermarkets' corporate brand image and reputation. Corp. Commun. Int. J. 2015, 20, 178-195. [CrossRef]

63. Popoli, P. Linking CSR strategy and brand image. Mark. Theory 2011, 11, 419-433. [CrossRef]

64. Flores-Hernández, J.A.; Cambra-Fierro, J.J.; Vázquez-Carrasco, R. Sustainability, brand image, reputation and financial value: Manager perceptions in an emerging economy context. Sustain. Dev. 2020. [CrossRef]

65. Abugre, J.B.; Anlesinya, A. Corporate social responsibility strategy and economic business value of multinational companies in emerging economies: The mediating role of corporate reputation. Bus. Strat. Dev. 2020, 3, 4-15. [CrossRef]

66. Pratihari, S.K.; Uzma, S.H.; Balmer, J. CSR and corporate branding effect on brand loyalty: A study on Indian banking industry. J. Prod. Brand Manag. 2018, 27, 57-78. [CrossRef]

67. Lai, C.-S.; Chiu, C.-J.; Yang, C.-F.; Pai, D.-C. The Effects of Corporate Social Responsibility on Brand Performance: The Mediating Effect of Industrial Brand Equity and Corporate Reputation. J. Bus. Ethics 2010, 95, 457-469. [CrossRef]

68. Heikkurinen, P.; Ketola, T. Corporate Responsibility and Identity: From a Stakeholder to an Awareness Approach. Bus. Strat. Environ. 2012, 21, 326-337. [CrossRef]

69. Perez, A.; Del Bosque, I.R. How Customer Support for Corporate Social Responsibility Influences the Image of Companies: Evidence from the Banking Industry. Corp. Soc. Responsib. Environ. Manag. 2015, 22, 155-168. [CrossRef]

70. Kim, S.; Park, H. Corporate social responsibility as an organization attractiveness for prospective public relations. J. Bus. Ethics 2011, 103, 639-653. [CrossRef]

71. Wagner, T.; Lutz, R.J.; Weitz, B.A. Corporate Hypocrisy: Overcoming the Threat of Inconsistent Corporate Social Responsibility Perceptions. J. Mark. 2009, 73, 77-91. [CrossRef]

72. Sen, S.; Bhattacharya, C.B. Does Doing Good Always Lead to Doing Better? Consumer Reactions to Corporate Social Responsibility. J. Mark. Res. 2001, 38, 225-243. [CrossRef]

73. Brown, T.; Dacin, P. The company and the product: Corporate associations and consumer product responses. J. Mark. 1997, 61, 68-84. [CrossRef]

74. Galbreath, J. Building corporate social responsibility into strategy. Eur. Bus. Rev. 2009, 21, 109-127. [CrossRef]

75. Ferrell, O.C.; Harrison, D.E.; Ferrell, L.; Hair, J.F. Business ethics, corporate social responsibility, and brand attitudes: An exploratory study. J. Bus. Res. 2019, 95, 491-501. [CrossRef] 
76. Anderson, J.; Narus, J. A model of distributor's perspective of distributor-manufacturer working relationships. J. Mark. 1984, 48, 62-74. [CrossRef]

77. Chang, H. Consumer socially sustainable consumption: The perspective toward corporate social responsibility, perspective value, and brand loyalty. J. Econ. Manag. 2017, 13, 167-191.

78. Webb, D.J.; Mohr, L.A.; Harris, K.E. A re-examination of socially responsible consumption and its measurement. J. Bus. Res. 2008, 61, 91-98. [CrossRef]

79. Becker-Olsen, K.L.; Cudmore, B.A.; Hill, R.P. The impact of perceived corporate social responsibility on consumer behavior. J. Bus. Res. 2006, 59, 46-53. [CrossRef]

80. He, H.; Li, Y. CSR and Service Brand: The Mediating Effect of Brand Identification and Moderating Effect of Service Quality. J. Bus. Ethics 2010, 100, 673-688. [CrossRef]

81. Coffie, S. Positioning strategies for branding services in an emerging economy. J. Strat. Mark. 2018, 28, 321-335. [CrossRef]

82. Odoom, R. Brand marketing programs and consumer loyalty-Evidence from mobile phone users in an emerging market. J. Prod. B. Manag. 2016, 25, 651-662. [CrossRef]

83. Smith, J.; Alexander, C. The companies with the best CSR reputations. Forbes, 2 October 2013.

84. Cambra-Fierro, J.J.; Polo-Redondo, Y. Long-term Orientation of the Supply Function in the SME Context. Int. Small Bus. J. Res. Entrep. 2008, 26, 619-646. [CrossRef]

85. Maden, C.; Arikan, E.; Telci, E.; Kantur, D.; Arıkan, E. Linking Corporate Social Responsibility to Corporate Reputation: A Study on Understanding Behavioral Consequences. Procedia-Soc. Behav. Sci. 2012, 58, 655-664. [CrossRef]

86. Neville, B.A.; Bell, S.; Mengüç, B. Corporate reputation, stakeholders and the social performance-financial performance relationship. Eur. J. Mark. 2005, 39, 1184-1198. [CrossRef]

87. Park, J.; Lee, H.; Kim, C. Corporate social responsibilities, consumer trust and corporate reputation: South Korean consumers' perspectives. J. Bus. Res. 2014, 67, 295-302. [CrossRef]

88. Keller, K.L. Conceptualizing, measuring, and managing customer-based brand equity. J. Mark. 1993, 57, 1-22. [CrossRef]

89. Mohammed, A.A.; Rashid, B. A conceptual model of corporate social responsibility dimensions, brand image, and customer satisfaction in Malaysian hotel industry. Kasetsart J. Soc. Sci. 2018, 39, 358-364. [CrossRef]

90. Grott, E.M.; Cambra-Fierro, J.; Perez, L.; Yani-De-Soriano, M. How cross-culture affects the outcomes of co-creation. Eur. Bus. Rev. 2019, 31, 544-566. [CrossRef]

91. Arndt, J. Role of product-related conversations in the diffusion of a new product. J. Mark. Res. 1967, 4, 291-295. [CrossRef]

92. Richins, M. Negative word-of-mouth by dissatisfied consumers: A pilot study. J. Mark. 1983, 47, 68-78. [CrossRef]

93. Jung, N.Y.; Seock, Y.-K. Effect of service recovery on customers' perceived justice, satisfaction, and word-of-mouth intentions on online shopping websites. J. Retail. Consum. Serv. 2017, 37, 23-30. [CrossRef]

94. Peruvian Institute of Statistics and Computing. Available online: https://www.inei.gob.pe/ (accessed on 15 December 2019).

95. Atradius. Available online: https://group.atradius.com/ (accessed on 10 July 2018).

96. Kok, W.; Fon, S. Shopper perception and loyalty: A stochastic approach to modeling shopping mall behavior. Int. J Ret. Dist. Manag. 2014, 42, 626-642.

97. Bush, A.; Hair, J. An assessment of the mall intercept as a data collection method. J. Mark. Res. 1985, 22, 158-167. [CrossRef]

98. Yani-De-Soriano, M.; Hanel, P.H.; Vazquez-Carrasco, R.; Cambra-Fierro, J.; Wilson, A.; Centeno, E. Investigating the role of customers' perceptions of employee effort and justice in service recovery. Eur. J. Mark. 2019, 53, 708-732. [CrossRef]

99. Keillor, B.D.; Lewison, D.; Hult, G.T.M.; Hauser, W. The service encounter in a multi-national context. J. Serv. Mark. 2007, 21, 451-461. [CrossRef]

100. Henseler, J. Bridging Design and Behavioral Research with Variance-Based Structural Equation Modeling. J. Advert. 2017, 46, 178-192. [CrossRef]

101. Rigdon, E.; Sarstedt, M.; Ringle, C. On comparingr from CB-SEM and PLS-SEM: Five perspectives and five recommendations. Mark. ZFP 2017, 39, 4-16. [CrossRef] 
102. Sarstedt, M.; Hair, J.F.; Ringle, C.M.; Thiele, K.O.; Gudergan, S. Estimation issues with PLS and CBSEM: Where the bias lies! J. Bus. Res. 2016, 69, 3998-4010. [CrossRef]

103. Tenenhaus, M.; Vinzi, V.E.; Chatelin, Y.-M.; Lauro, C. PLS path modeling. Comput. Stat. Data Anal. 2005, 48, 159-205. [CrossRef]

104. Carmines, E.; Zeller, R. Reliability and Validity Asses Sment; Sage: Thousand Oaks, CA, USA, 1979.

105. Nunnally, J. Psychometric Theory, 2nd ed.; McGraw-Hil: New York, NY, USA, 1978.

106. Fornell, C.; Larcker, D. Evaluating structural equation models with unobservable variables and measurement error. J. Mark. Res. 1981, 18, 39-50. [CrossRef]

107. Falk, R.; Miller, N. A Primer for Soft Modeling; University of Akron Press: Akron, OH, USA, 1992.

108. Kumar, V.; Pozza, I.D.; Ganesh, J. Revisiting the Satisfaction-Loyalty Relationship: Empirical Generalizations and Directions for Future Research. J. Retail. 2013, 89, 246-262. [CrossRef]

109. Podsakoff, P.; MacKenzie, S.; Lee, J.; Podsakoff, N. Common method biases in behavioral research: A critical review of the literature and recommended remedies. J. Appl. Psychol. 2003, 88, 879-903. [CrossRef]

(C) 2020 by the authors. Licensee MDPI, Basel, Switzerland. This article is an open access article distributed under the terms and conditions of the Creative Commons Attribution (CC BY) license (http://creativecommons.org/licenses/by/4.0/). 